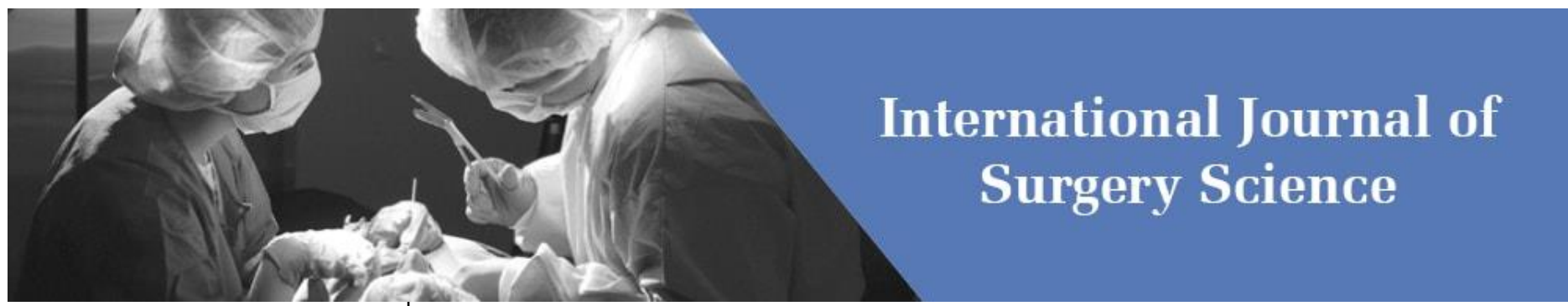

E-ISSN: 2616-3470

P-ISSN: 2616-3462

(C) Surgery Science

www.surgeryscience.com

$2020 ; 4(1): 454-457$

Received: 22-11-2019

Accepted: 25-12-2019

Duraid Dawood Mahmood

Deportment of Surgery, Fallujah

Teaching Hospital, Fallujah,

Anbar, Iraq

Abdulhadi Meryud Abood

Deportment of Surgery, Fallujah

Teaching Hospital, Fallujah,

Anbar, Iraq
Corresponding Author:

Duraid Dawood Mahmood

Deportment of Surgery, Fallujah

Teaching Hospital, Fallujah,

Anbar, Iraq

\section{Opened versus closed procedures in management of pilonidal sinus (P.M.S.)}

\section{Duraid Dawood Mahmood and Abdulhadi Meryud Abood}

DOI: https://doi.org/10.33545/surgery.2020.v4.i1h.385

\section{Abstract}

Background: PNS is a common surgical disease and there are many methods of treatment such as wide excision of sinus and lay wound open to heal by granulation tissue (open), excision of a sinus with primary closure (closed), track debridement and excision or phenolization of epithelial pit and excision of PNS with primary closure using oblique incision.

\section{Methods:}

Setting: In Fallujah Teaching Hospital from Jan. 2017 to Dec. 2018.

Design: Prospective study.

These cases were chosen and divided into 2 groups: Group A: were treated by open procedure (31).

Group B: were treated by closed procedure (27).

The average period of follow up after completion of surgery was six months for both groups.

Results: In group A symptomatic improvement occurs in $26(83.8 \%)$ of patients and the duration of healing was about 45 days, $5(16.2 \%)$ patients were delayed healing while recurrence were $4(12.9 \%)$.

In group B symptomatic improvement occurs in $19(73.7 \%)$ of patients and the duration of healing was about 2 weeks. $8(26.3 \%)$ patients were delayed healing while recurrence were $6(22.2 \%)$.

Conclusions: From this study we find that there is no ideal treatment of pilonidal sinus according to:

1. Meantime of healing.

2. Delay healing.

3. Recurrence.

Keywords: Pilonidal sinus Pilonidal cavity.

\section{Introduction}

A pilonidal sinus is formed when granulation lined pilonidal cavity drains via a sinus tract which open away from midline as an area of proud granulation onto the skin. During an interval between episodes of inflamma-tion, the diagnosis can be confirmed by identifying the epithelialized follicle opening within the natal cleft $4-8 \mathrm{~cm}$ cephalad from anus.

The sinus track then runs cephalad from this midline opening in roughly $93 \%$ of cases 1 and can usually be palpated as area indurations deep to the sacral skin. Not infrequently there may be more than one epithelialized opening within the natal cleft but the laterally situated granulation lined opening is single in cases have not undergone surgery ${ }^{[2]}$

Sacro-coccygeal pilonidal sinus is well known for its association with military personnel ${ }^{[3]}$ one of its commoner synonyms Jeep seat disease's. Today PNS are widely accepted to be acquired abnormalities ${ }^{[4,5]}$.

As a result of the droinge of a hair follicle ${ }^{[6]}$. That ruptured in the subcutaneous fat, producing acute or chronic in Flomaton ${ }^{[7]}$, resulting in an abscess or tract ${ }^{[5]}$.

The invasion of the follicle occurs through the expendable orifice of the vestigial scent gland ${ }^{\text {[7] }}$ and is a result of inflammation and rupture in the subcutaneous fat of the follicle ${ }^{[7,8]}$.

However more recent prospective study of 49 infected postoperative wounds isolated aerobic bacteria in $43 \%$ of cases ${ }^{[11]}$. Treatment of pilonidal infection should be with broad spectrum antibiotics.

\section{The Aim of the Study}

This prospective study aim to compare between wide excision and laying wound open to heal by granulation tissue, and excision of the sinus with primary closure in:

1. Mean time of healing. 
2. Delay healing.

3. Recurrence.

\section{Patients and Methods}

58 cases of PNS were included in the study from (Jan. 2017Dec. 2018). All the patients treated at Fallujah Teaching Hospital.

They were categorized into 2 groups, group 1 (31) patients were treated by opened procedure, group 2 (27) patients were treated by closed procedure.

Both groups admitted to the hospital, history was taken and general examination was done. All patients had shaved their hairs in and around the natal cleft one day before operation and treated under general anesthesia.

\section{PNS excision -healing by open granulation: Indications: \\ 1. History of more than one year. \\ 2. Second hand surgery. \\ 3. Infected sinus.}

This procedure was done to group 1 .

At operation patient put in prone position with a buttock haled a part by strapping. A probe was passed in every sinus to delineate the extent of disease.

Treatment was by conservative excision of the skin to include the sinuses openings deep to the sacral fascia and total excision of the tracks to leave well-shaped wound.

This was packed with gauze soaked in proflavin paraffin emulsion for 3 days. Then dressing changed twice daily, the patient were trained to bath their wound and change their dressing twice daily after one week patient discharged to the clinic for weekly observation and removal of the dressing. When the wound fill and contracted the paraffin gauze replaced by dry gauze- poorly drainage packet in the wound were opened up with forceps. The patient re-attend the clinic regularly until their wound healed or until were referred for further surgery.

\section{All patients were given}

1. Analgesia (paracetamol $500 \mathrm{mg}$ orally on need).

2. Antibiotic: Amoxicillin 500mg 8 hourly for one week, this $>$ antibiotic has broad spectrum activity.

3. Patients were advised to change their work.

\section{PNS excision-healing by primary closure: Indications:}

1. Newly diagnosed patients with history less than one year and single sinus opening.

2. Minimal patient visit after operation only for 2 weeks.

At operation the patient was put in prone position with a buttock healed a part by strapping. A probe was passed in every sinus to delineate the extent of disease. An elliptical block of tissue extending down to sacral fascia was removed.

Its long axis was in the natal cleft and its lateral border was over $1 \mathrm{~cm}$ distant from all sinuses. Specimens were examined at the time to confirm that the excision had been adequate. Redivac drain was brought out $2 \mathrm{~cm}$ lateral to the lower end of the wound. Closure was with interrupted No.1 monofilament Nylon stitches passed from a point $1 \mathrm{~cm}$ wide of the skin edges down to and including the sacral fascia. These were tied over a gauze roll after the skin had been sutured with interrupted $2 / 0$ mer silk. No attempt was made to occlude the wound from perineal region. Administration of tetracycline $250 \mathrm{mg} 4$ times daily started immediately after operation and continued for 1 week and paracetamol on need.
The drain was removed when collection was under $10 \mathrm{ml}$ in $24 \mathrm{hr}$ and patient discharged the other day, seen weekly intervals until complete healing.

\section{Results}

It is randomized prospective study which was carried out in the surgical department in Fallujah Teaching Hospitals during the period of Jan. 20017 - Dec. 2018.

58 patients included $51(88 \%)$ men and $7(12 \%)$ women. The men age ranges from 18-35 years, and women ages' ranges from 16-30 years.

They were categorized into 2 groups; group A, 31 (53.4\%) patients were treated with excision of the sinus and laid wound open and group B 27 (46.4\%) patients were treated with primary closure.

The results of group A we found that the mean time to healing is 45 days and $5(16.2 \%)$ patients were delayed healing while recurrence were $4(12.9 \%)$ with 6 month follow up.

The results of group B we found that the mean time to healing is 2 weeks and $8(26.3 \%)$ patients were delayed healing and the recurrence $6(22.2 \%)$ patients.

Table 1: Clinical data on 58 patients in two sexes

\begin{tabular}{|c|c|c|}
\hline & Male & Female \\
\hline No. of patients & 51 & 7 \\
\hline Age (years) & $18-35$ & $16-30$ \\
\hline Range Mean & 25 & 20 \\
\hline History & & \\
\hline 6 months & 20 & 1 \\
\hline$>2$ years & 34 & 3 \\
\hline$>2$ years & 13 & 3 \\
\hline Previous treatment & 14 & 2 \\
\hline Drainage Radical & 6 & - \\
\hline
\end{tabular}

Table 2: Comparison between two groups after sur- gical treatment.

\begin{tabular}{|c|c|c|c|c|}
\hline Method & $\begin{array}{c}\text { No. of } \\
\text { cases }\end{array}$ & $\begin{array}{c}\text { Mean time } \\
\text { of } \\
\text { healing/day }\end{array}$ & $\begin{array}{c}\text { Delay- } \\
\text { healing } \\
\text { time }\end{array}$ & Recurrence \\
\hline $\begin{array}{c}\text { Group A } \\
\text { (laying open) }\end{array}$ & 31 & 45 & 5 & 4 \\
\hline $\begin{array}{c}\text { Group B } \\
\text { (primary closure) }\end{array}$ & 27 & 14 & 8 & 6 \\
\hline
\end{tabular}

\section{Discussion}

Pilonidal disease affects men ${ }^{[12,13]}$ between $16-25$ years of age most often usually it is associated with obese 14, 15 and hirsute individuals who experience profuse sweat-ing and have sedan tarry life style ${ }^{[16,17]}$.

The term "delayed healing" was applied to those wounds not completely closed by 2 months (4).

In J Mark, K.G. Harding study (10) he consider the main cause of delayed healing and recurrence was infection by anaerobic bacteria particularly.

He said that the term "recurrence" is frequently used incorrectly, as the majority of sinuses requiring re-operation result from delayed healing due to inade- quate excision.

In our study we saw that the main causes of delayed healing and recurrence:

1. Infection.

2. Patients with longer histories more than 2 years.

3. Poor hygiene patients' and patient whom doesn't regulate their visits at weekly intervals to outpa- tients and clinics. 


\section{Causes of recurrence}

The recurrence rate at one year following open methods of treatment is less than after primary closure (2) possi- ble reason for this:

1. The midline scar is more susceptible to subsequent hair perforation than after healing by granulation.
2. The broader scar after healing by granulation re- duces local hair growth.

3. There are fewer hair follicles near the midline to produce further folliculitis.

4. The broader scar resulting from secondary healing flattens the natal cleft to reduce buttock friction.

Table 3, 4: Show us comparison between our studies in both groups with the other previous studies by the two methods. We use to treat patients from 1967-1987 year

\begin{tabular}{|c|c|c|c|c|}
\hline References & Year & No. of cases & Mean time of healing (day) & Recurrence (\%) \\
\hline Goodall & 1961 & 15 & - & 0 \\
\hline Notaras & 1970 & 45 & 42 & 9 \\
\hline Sood et al. & 1975 & 23 & 29 & 11 \\
\hline Ortiz et al. & 1977 & 14 & 38 & $<20$ \\
\hline Houston & 1977 & 25 & 31 & 4 \\
\hline Weinstein & 1977 & 126 & $<60$ & 0 \\
\hline Wood et al. & 1977 & 131 & 56 & - \\
\hline Britton et al. & 1977 & 42 & - & 26 \\
\hline Eftaiha et al. & 1977 & 175 & 42 & 14 \\
\hline Hodgson and Greenstein & 1981 & 10 & - & - \\
\hline Thomson and Lee & 1982 & 34 & $<60$ & 0 \\
\hline Clothier and Haywood & 1984 & 12 & - & \\
\hline McLaren & 1984 & 18 & 42 & \\
\hline Bissett and Isbister & 1987 & 48 & 48 & \\
\hline
\end{tabular}

Table 4: Mean healing time, primary healing and recurrence following piolonidal sinus excision with primary closure

\begin{tabular}{|c|c|c|c|c|c|}
\hline References & Year & No. of cases & $\begin{array}{l}\text { Mean time of } \\
\text { healing (day) }\end{array}$ & $\begin{array}{c}\text { Failed primary } \\
\text { healing }(\%)\end{array}$ & Recurrence (\%) \\
\hline Leichtling & 1967 & 11 & 14 & 9 & 0 \\
\hline Cherry & 1968 & 15 & 14 & - & - \\
\hline Thomas & 1968 & 57 & - & - & 12 \\
\hline Holm and Hutton & 1970 & 50 & $<10$ & 6 & 4 \\
\hline Foss & 1970 & 90 & 17 & 11 & $<20$ \\
\hline Notaras & 1970 & 43 & 12 & 30 & 9 \\
\hline Schonk & 1971 & 75 & 16 & 11 & 4 \\
\hline Tetirick & 1971 & 15 & - & 8 & 0 \\
\hline Euangelous and Tiniakus & 1974 & 34 & 10.5 & 12 & - \\
\hline Lamke et al. & 1974 & 39 & 23 & 2 & 26 \\
\hline Uerbeck and Bender & 1974 & 711 & - & 3.5 & 14 \\
\hline Sood et al. & 1975 & 75 & 50 & - & 11 \\
\hline Kam & 1976 & 36 & $<10$ & 6 & - \\
\hline Bentiuegna and Procaio & 1977 & 83 & 10 & 0 & 0 \\
\hline Britton et al. & 1977 & 51 & - & - & 20 \\
\hline Zimmerman & 1978 & 82 & 14 & 0 & 0 \\
\hline Rainbury and Southam & 1982 & 27 & $<30$ & 8 & 1 \\
\hline Clothier and Haywood & 1984 & 24 & - & - & 37 \\
\hline McLaren & 1984 & 14 & 11 & - & 12 \\
\hline Kronberg et al. & 1986 & 33 & 14 & - & 15 \\
\hline Courtyney and Merlin & 1986 & 81 & 12 & - & 13 \\
\hline Bissett and Isbister & 1987 & 57 & 30 & - & 28 \\
\hline
\end{tabular}

\section{Conclusions}

The results of our study indicates that the ideal treatment of pilonidal. Sinus should avoid hospital admission and general anesthesia while involving minimal inconvenience and time off work for the patient with high chance of cure and low recurrence rate.

So management of pilonidal sinus is frequently unsatisfactory.

\section{Recommendations}

There is no ideal method in management of pilonidal sinus that satisfy all requirement for ideal treatment quick healing, no hospital admission, minimal patient inconvenience and recurrence, so in group A more time for healing, more patient inconvenience and more work up by doctor and nurses but less recurrence; while group B quick healing, less work for patient and surgical staff and less patient inconvenience but increase percentage of delay healing and recurrence.

\section{References}

1. Notaras MJ. A review of three popular methods of treatment of post-anal pilonidal sinus disease. British Medical Journal of Surgery. 1970; 7:889-90.

2. Allen-Mersh TG. A review of pilonidal sinus: Finding the right track for treatment. British Medical Journal of Surgery. 1998; 77:123-132.

3. Peter Clothier. The natural history of the post-anal pilonidal sinus. Ann. Royal College of surgeons- England. 1984; 66:201-204. 
4. King ES. The nature of the pilonidal sinus. Aust NZJ Surg. 1947, 182-192.

5. Patey DH, Scar ff RW. Pathology of postnatal pilonidal sinus; its beoring on treatment. Lancet. 1946; 2:484-486.

6. Bascom. Pilonidal disease: origin from follicles of hairs and results of folic b removal as treatment. Surgery. 1980; 87:567-572.

7. Bascom J. Pilonidal disease: long term results of follicle removal. Dis cotton Rectum. 1983; 26:800-807.

8. Bascom J, Bascom T. Failed pilonidal surgery: new paradigm and new operation leading to cures. Arch Surg. 2002; 137:1146-1151.

9. Richard M, Ramsbary, John, Southam A. Radical surgery for pilonidal sinus. Ann. Royal College of surgeonsEngland. 1982; 64:339-41.

10. Hodges RM. Pilonidal sinus. Boston Med Surge J. 1980; 103:485-586

11. Sondenaa K, Nesvi K, Nesvi I, Anderson E et al. Bacteriology and complication of chronic pilonidal sinus treatment with excision and primary su- ture. Int $\mathrm{J}$ colorectal Dis. 1995; 10(3):161-66.

12. Karydokis GF. New approach to the problem of pilonidal sinus. Lancet. 1973; 2:1414-1415.

13. Clothier PR, Haywood IR. The natural history of the post anal (pilonidal) nisvs. Ann R coll Surg Engle. 1984; 66:201203.

14. Bascom J. Surgical treatment of pilonidal disease. BMJ. 2008; 336:842-843.

15. Menzel T, Dorner A, Cramer J. [Excision and open wound treatment of pilonidal sinus. Rate of recurrence and duration of work incapacity]. Dtsch Med Wochenschr. 1997; 122:1447-1451.

16. Kronborg O, Christensen K, Zimmermann- Niel- sen C. Chronic pilonidal disease: a randomized trial with a complete 3 year follow-up. Br J Surg. 1985; 72:303-304. 